\title{
Oxygen tension and oocyte density during in vitro maturation affect the in vitro fertilization of bovine oocytes
}

\section{A tensão de oxigênio e a densidade de oócitos durante a maturação in vitro afeta a fecundação in vitro de oócitos bovinos}

\author{
Angelo Bertani Giotto'; Daniela dos Santos Brum²; Francielli Weber Santos²; \\ Antonio Carlos Galarça Guimarães ${ }^{1}$; Cibele Garcia Moreira Gonçalves ${ }^{1}$; \\ Cecilia Urquiza Machado Pavin ${ }^{1}$; Natalia Picoli Folchini³; \\ Aline Barros Moyses ${ }^{3}$; Daniele Missio ${ }^{3}$; Fábio Gallas Leivas ${ }^{4 *}$
}

\begin{abstract}
Oocyte maturation is the key factor affecting the fertilization and embryonic development. Factors such as oocyte density and oxygen tension can directly influence the IMV. Thus, the objective of this study was to evaluate the effect of the association of oxygen tensions (5\% or $20 \%$ ) with different oocyte densities $(1: 10 \mu 1$ or $1: 20 \mu 1)$ in the in vitro maturation (IVM) of bovine oocytes on maturation and fertilization rates, ROS production and antioxidant activity. Three experiments were performed with bovine oocytes that were obtained from slaughterhouse ovaries. After selection, the oocytes were randomly distributed in four treatments: $1: 10 / 5 \% ; 1: 10 / 20 \% ; 1: 20 / 5 \%$ and $1: 20 / 20 \%$ for each experiment. In experiment I, nuclear maturation status and cytoplasmic maturation were evaluated through detection of the first polar body by immunofluorescence and the mitochondrial reorganization assay. In experiment II, ROS production and antioxidant activity were analyzed in oocytes and IVM medium after $24 \mathrm{~h}$ of maturation through detection of ROS, reduced glutathione (GSH) and Superoxide dismutase activity by spectrofluorimetric methods. In experiment III, fertilization was evaluated through pronucleus formation, sperm penetration with or without decondensation and polyspermy rates by immunofluorescence. In experiment $\mathrm{I}$, the nuclear maturation and cytoplasmic maturation were similar among treatments $(\mathrm{P}>0.05)$. In experiment II, reactive oxygen species in oocytes were elevated in treatments with low oxygen tension which was independent of oocyte density $(\mathrm{P}<0.05)$. Additionally, ROS levels in IVM medium were higher in treatments with high oocyte density by volume of medium, which was independent of oxygen tension $(\mathrm{P}<0.05)$. In Experiment III, the fertilization and penetration rates were higher in the treatment with $20 \%$ oxygen tension and high oocyte density $(\mathrm{P}<0.05)$. Furthermore, a high incidence of polyspermy was observed in groups with high oxygen tension and low oocyte density $(\mathrm{P}<0.05)$. In conclusion, the results of this study indicate an interaction between oxygen tension and oocyte density, which increases ROS production in certain associations and subsequently influences the rates of in vitro fertilization of bovine oocytes. The improved rates of IVF were obtained when IVM was conducted using $20 \%$ oxygen tension and high oocyte density $(1: 20 \mu 1)$.
\end{abstract}

Key words: Oocyte density, oxygen tension, ROS production, superoxide dismutase, GSH

\footnotetext{
${ }^{1}$ Discentes do Programa de Pós Graduação em Ciência Animal, Universidade Federal do Pampa, UNIPAMPA, Uruguaiana, RS, Brasil.E-mail: angelob.giotto@hotmail.com; acarlosgalarca@hotmail.com; cibelegmg@gmail.com; cecilia_machado@msn.com

2 Profs. Associados, UNIPAMPA, Uruguaiana, RS, Brasil. E-mail: danisbrum@yahoo.com.br; francielliweber@yahoo.com.br

${ }^{3}$ Discentes do curso de Medicina Veterinária, UNIPAMPA, Uruguaiana, RS, Brasil. E-mail: nataliafolchini@hotmail.com; alinebmoyses@hotmail.com; daniele.missio@yahoo.com.br

${ }^{4}$ Prof. Adjunto, UNIPAMPA, Uruguaiana, RS, Brasil. E-mail: fabioleivas@yahoo.com.br

* Author for correspondence
} 


\section{Resumo}

A maturação dos oócitos é o fator chave que afeta a fecundação e o desenvolvimento embrionário. Fatores como a densidade de oócitos e a tensão de oxigênio podem influenciar diretamente a maturação in vitro (MIV) de oócitos bovinos. O objetivo do presente estudo foi avaliar o efeito da associação da tensão de oxigênio ( $5 \%$ ou $20 \%$ ) com diferentes densidades de oócitos $(1: 10 \mu 1$ ou 1:20 $\mu 1)$ MIV de oócitos bovinos, na taxa de maturação, fecundação, produção de espécies reativas ao oxigênio (ROS) e defesas antioxidantes. Três experimentos foram conduzidos com oócitos obtidos de ovários de abatedouro. Após a seleção, os oócitos foram distribuídos homogeneamente em quatro tratamentos: 1:10/5\%; $1: 10 / 20 \% ; 1: 20 / 5 \%$ e $1: 20 / 20 \%$. No experimento I, o status da maturação nuclear e citoplasmática foram avaliados pela detecção do primeiro corpúsculo polar por epifluorescência e avaliação da reorganização das mitocôndrias. No experimento II, a produção de EROs e atividade antioxidante foram analisadas nos oócitos e no meio de MIV após $24 \mathrm{~h}$ de maturação pela detecção de ROS, redução da glutationa (GSH) e atividade da Superoxido Dismutase por métodos de espectrofluorometria. No experimento III, foram avaliadas as taxas de fecundação pela formação dos pro-núcleos, penetração com ou sem descondensação espermática e poliespermia por epifluorescência. No experimento I, a maturação nuclear e citoplasmática foi similar entre os tratamentos $(\mathrm{P}>0,05)$. No experimento II, os níveis de ROS nos oócitos foram elevados nos tratamentos com baixa tensão de oxigênio (5\%) independente da densidade de oócitos $(\mathrm{P}<0,05)$. Adicionalmente os níveis de ROS no meio de MIV foram maiores nos tratamentos com alta densidade de oócitos por volume de meio, independente da tensão de oxigênio $(\mathrm{P}<0,05)$. No experimento III, a taxa de fecundação e penetração espermática foi maior nos tratamentos com $20 \%$ de oxigênio e alta densidade de oócitos $(\mathrm{P}<0,05)$. Entretanto, alta incidência de polispermia foi observada nos grupos com alta tensão de oxigênio (20\%) e baixa densidade de oócitos (1:20). Em conclusão, os resultados deste estudo indicam uma interação entre tensão de oxigênio e densidade de oócitos, que aumenta a produção de ROS em certas associações e consequentemente influencia as taxas de fecundação dos oócitos bovinos. O aumento nas taxas de fecundação é obtido utilizando uma tensão de 20\% de oxigênio e alta densidade de oócitos (1:20 ul).

Palavras-chave: Densidade de oócitos, tensão de oxigênio, produção de EROs, superóxido dismutase, GSH

\section{Introduction}

The in vitro maturation (IVM) of bovine oocytes has an important role in in vitro embryo production. The nuclear maturation rates in oocytes that are matured in vitro can be approximately $90 \%$ (LONERGAN et al., 2003), although only 30 to $35 \%$ of the matured oocytes reach the blastocyst stage. However, following in vivo maturation and subsequent in vitro fertilization (IVF), these rates increase to 60 to $80 \%$ (BLONDIN et al., 2002; RIZOS et al., 2002), which indicates that oocyte maturation is the key factor affecting blastocyst development. Therefore, improvements in the conditions of IVM, such as oocyte quality, IVM medium, atmospheric conditions and oocyte density, would be useful in enhancing blastocyst production. The most common atmospheric tension that is used for IVM is $5 \% \mathrm{CO}_{2}$, with $20 \% \mathrm{O}_{2}$. This tension is higher than the tension that is observed in the female reproductive tract and follicular fluid, which ranges between 1.3 and $8.5 \% \mathrm{O}_{2}$ (BANWELL et al., 2007). Oxygen tension has an important role in cell activity in many cell types, such as oocytes, somatic cells, stem cells and embryos (HIRAO et al., 2012). Some studies demonstrated that lower oxygen tension $(5 \%)$ during IVM resulted in higher embryo production (HASHIMOTO et al, 2000, 2009; MILLER; RORIE, 2000; BERMEJOALVAREZ et al., 2010), whereas other studies reported detrimental effects under the same conditions (CASTRO E PAULA; HANSEN, 2007; PINYOPUMMINTR; BAVISTER, 1995). Adam et al. (2004) demonstrated better cleavage rates in mouse oocytes maturing in low oxygen tension $(5 \%)$. Recently was demonstrated that oxygen 
concentration influences in murine cumulus cell gene expression during IVM (KIND et al., 2015). In humans, both 5 and $20 \%$ oxygen tension have been used for IVM (BERMEJO-ALVAREZ et al., 2010). Leivas et al. (2006) did not find differences in rates of cleavage, blastocyst and pregnancy when the bovine oocytes were matured, fertilized and cultured in 5 or $20 \%$ oxygen tension.

Another factor that can influence IVM is the oocyte density by medium volume. When the oocytes are cultured in groups, the rates of blastocyst are better than when cultured alone or in groups of less than 10 oocytes (BRUM et al., 2005; O'DOHERTY et al., 1997). However, high oocyte density can increase the competition between cumulus cells and oocytes for oxygen (PINYOPUMMINTR; BAVISTER, 1995) and can affect the availability of oxygen, which is necessary for the oocyte to complete maturation. Another factor that can interfere with oocyte maturation is the excessive production of reactive oxygen species (ROS), which is increased by high oxygen tension $(20 \%)$ (FOWLER; CALLINGHAM, 1978; GUÉRIN et al., 2001; HASHIMOTO et al., 2000; YANG et al., 1998). An inadequate association between oxygen tension and oocyte density can contribute to an increase in ROS and can induce oxidative stress. For the regulation of ROS, the cell has an antioxidant system, which is based on enzymatic, assuperoxide dismutase (SOD), and non-enzymatic protection as glutathione (GSH). Oxidative stress can also affect the mechanism of calcium release (GOUD et al., 2008), which regulates the reorganization of cortical granules (ABBOTT; DUCIBELLA, 2001) and directly influences the process of fertilization. GSH is an important non-enzymatic antioxidant and is present in oocytes in varying degrees (MIYAMURA et al., 1995; CETICA et al., 2001). Studies have already demonstrated in pigs, hamsters and mice that GSH plays an important role in oocyte protection against oxidative damage and also in the male pronucleus formation after sperm penetrationwith an important role in decondensation of sperm (MATOS;
FURNUS, 2000). The interactions of oxygen tension with various factors that affect maturation dynamics have been studied (KIND et al., 2015; MARQUES et al., 2012; HASHIMOTO et al., 2000); however, to the best of our knowledge, the interaction between oxygen tension and oocyte density has not been described. The aim of this study was to evaluate how different oxygen tensions (5 or 20\%) and oocyte densities by medium volume (1:10 or 1:20) affect bovine oocyte maturation and fertilization in vitro.

\section{Materials and Methods}

All the reagents and chemicals that were utilized in this study were acquired from Sigma Aldrich (St. LouisMO, USA). Other sources of the reagents and chemicals will be cited.

\section{Oocyte recovery and selection}

The oocytes that were used in this study were recovered from bovine ovaries that were collected from a slaughterhouse and that were transported to the laboratory in a $0,9 \% \mathrm{NaCl}$ solution supplemented with streptomycin, potassium benzylpenicillin and procaine benzylpenicillin added (Agrovet 500.000, Novartis, Eurofarma Laboratórios, Brazil). For this study, 2 - $8 \mathrm{~mm}$ follicles were aspirated with an 18 $\mathrm{G}$ needle on a vacuum pump and 1 and 2 quality oocytes were selected (LOOS et al., 1989).

\section{In vitro maturation}

The oocytes were matured in TCM 199 medium with $10 \%$ estrous mare serum, $100 \mu \mathrm{g}$ $\mathrm{ml}^{-1}$ epidermal growth factor (EGF), $50 \mu \mathrm{g} / \mathrm{ml}^{-1} \mathrm{LH}$ (Lutropin, Bioniche, Ontario, Canada), $5 \mu \mathrm{g} / \mathrm{ml}^{-1}$ FSH (Folltropin, Bioniche, Ontario, Canada) and $22 \mathrm{mg} / \mathrm{ml}^{-1}$ pyruvate. The oocytes were maintained in maturation medium $(300 \mu 1)$ for $22-24$ hours in an incubator at $39^{\circ} \mathrm{C}$, in groups of $15(1: 20)$ or 30 (1:10) oocytes according to the treatment described in experimental. 


\section{In vitro fertilization}

After the IVM period, the oocytes were washed in TCM HEPES and transferred to a dish containing $300 \mu$ FERT medium, which contained $6 \mathrm{mg} \mathrm{ml}^{-1}$ bovine serum albumin (BSA), $10 \mu \mathrm{g} \mathrm{ml}^{-1}$ heparin, $20 \mu \mathrm{M}$ penicillamine, $10 \mu \mathrm{g}$ hypotaurine and $2 \mu \mathrm{M}$ epinephrine.

The sperm were selected by separation using different Percoll density gradients, which included densities of 90, 60 and 30\% (FOLCHINI et al., 2012). Commercial semen from the Bos Taurus bull was utilized for the fertilization.

After the sperm selection, all treatments were inseminated with $2 \times 10^{6} \mathrm{sptz} / \mathrm{ml}^{-1}$ in droplets of $200 \mu \mathrm{L}$ and co-incubated for 18 hours at $39^{\circ} \mathrm{C}$, with saturated humidity in $5 \% \mathrm{CO}_{2}$.

\section{Cytoplasmic maturation evaluation}

Denuded oocytes were co incubated for 30 min with Mitotracker Green FM (MT; Molecular Probes INC, USA), which was at a concentration of $250 \mathrm{nM}$ in TCM 199 HEPES, and the oocytes were evaluated using a fluorescence microscope with an excitation wavelength of $490 \mathrm{~nm}$ and anemission wavelength of $516 \mathrm{~nm}$. For cytoplasmic maturation $(\mathrm{CM})$, the mitochondrial reorganization assay method (STOJKOVIC et al., 2001) was used. Oocytes that presented homogenous mitochondrial dispersion and distribution in the cytoplasm were considered oocytes which underwent CM. Oocytes that had mitochondria in the peripheral cytoplasm or that had vacuoles in the cytoplasm were considered lacking mitochondrial organization.

\section{Nuclear maturation evaluation}

Denuded oocytes were incubated with $10 \mu \mathrm{g}$ $\mathrm{ml}^{-1}$ bisbenzimide (Hoechst 33342) and evaluated using a fluorescence microscope with an excitation wavelength of $365 \mathrm{~nm}$ and an emission wavelength of $410 \mathrm{~nm}$. The oocytes that had the extrusion of the first polar body were considered oocytes which underwent nuclear maturation. The oocytes without the first polar body were considered immature.

\section{Evaluation of the production of Reactive oxygen} species

After 24 hours of IVM, the oocytes were denuded, washed in TCM HEPES, transferred to $100 \mu \mathrm{l}$ Tris- $\mathrm{HCl}, \mathrm{pH} 7.4$ and stored at $-20^{\circ} \mathrm{C}$. When all replications were finished, the samples were evaluated. After the IVM period, reactive oxygen species levels in oocytes and in the maturation medium were determined by the spectrofluorimetric method, utilizing 2'7'dichlorofluorescein diacetate (DCHF-DA) (LOETCHUTINAT et al., 2005). The samples were incubated with $10 \mu$ DCHF-DA (1 $\mathrm{mM})$ in the dark. The marker for ROS detection was DCHF-DA, which oxidizes to fluorescent dichlorofluorescein. The intensity emission of the fluorescence was $520 \mathrm{~nm}$, with an excitation wavelength of $480 \mathrm{~nm}, 30$ minutes after DCHF-DA was added to the medium.

\section{Evaluation of GSH levels and SOD activity}

After 24 hours of IVM, the oocytes were denuded, washed once in TCM HEPES and three times in PBS Calcium and magnesium free. Groups of 15 oocytes were frozen in $60 \mu 1$ PBS plus PVP at $-20^{\circ} \mathrm{C}$ and thawed at room temperature for three times for total cell disruption (MATOS; FURNUS, 2000).

GSH levels were determined by the spectrofluorimetric method (HASHIMOTO et al, 2000; HISSIN; HILF, 1976), using o-phthalaldehyde (OPA) as the fluorophore. The oocyte sample (10 $\mu \mathrm{l})$ was incubated with $10 \mu \mathrm{l}$ of OPA $(0.1 \%$ in methanol) and $180 \mu \mathrm{l}$ of $0.1 \mathrm{M}$ phosphate buffer $(\mathrm{pH} 8.0)$ for $15 \mathrm{~min}$ at room temperature in the dark. Fluorescence was measured with a Hidex Plate Chameleon V Multitechnology Plate reader (425-156 Model) at an excitation wavelength of 350 
$\mathrm{nm}$ and at an emission wavelength of $420 \mathrm{~nm}$. GSH levels were expressed as nmol GSH $\mathrm{mL}^{-1}$.

Superoxide dismutase activity was measured with a method that was based on the ability of SOD to inhibit the auto-oxidation of epinephrine to adrenochrome (CETICA et al., 2001). The color reaction can be monitored at $480 \mathrm{~nm}$. One enzymatic unit (1 UI) is defined as the amount of enzyme that is necessary to inhibit the auto-oxidation rate by $50 \%$ at $26{ }^{\circ} \mathrm{C}$.

\section{Evaluation of In vitro fertilization}

After 18 hours of co-incubation of the oocytes and spermatozoa, fertilization was evaluated. For the evaluation, $10 \mu \mathrm{g} \mathrm{ml} \mathrm{m}^{-1}$ bisbenzimide (Hoechst 33342) was utilized under an epifluorescent microscope, with the excitation wavelength at $365 \mathrm{~nm}$ and with the emission wavelength at 410 $\mathrm{nm}$. The fertilization was evaluated by pronucleus formation, sperm penetration with or without decondensation and polysperm rates. Zygotes that had two pronucleus formation and extrusion of the second polar body or that had extrusion of the second polar body and one sperm in decondensation were considered fertilized oocytes. Oocytes that had only one penetrated sperm were considered penetrated. Polyspermy was measured by two or more penetrated sperm.

\section{Statistical analyses}

The effects of oocytes density (1:10 or 1:20), oxygen tension ( $5 \%$ or $20 \%)$ and interactions were analyzed using a GLM procedure and the means were compared by Tukey's test. Percentages of nuclear and cytoplasmic maturation status were based on the number of matured oocytes compared with the total number of evaluated oocytes. These data were analyzed by an ANOVA and Tukey's test. For ROS production, an ANOVA and Tukey's test were utilized to analyze the units of fluorescence of oocytes and in the maturation medium. All of the statistical analyses were performed with SAS/ IML software release 8.2 (SAS Institute Inc., 2001). The fertilization evaluation data were analyzed by Z-test. The level of significance was $5 \%$.

\section{Experimental design}

This study was performed in three experiments where bovine oocytes were matured under different oxygen tension (5 or $20 \%$ ), which was associated with different densities of oocytes by the medium volume (1:10 or 1:20 oocyte per microliters). Experiment I was performed to evaluate the nuclear and cytoplasmic maturation of oocytes. Experiment II evaluated ROS production and the antioxidant system of the oocyte. Experiment III evaluated the in vitro fertilization.

In all experiments, the oocytes were obtained from slaughterhouse bovine ovaries, which were selected according to Loss et al. (1989) and were randomly distributed in each treatment: Treatment 1:10/5\% (1 oocyte per $10 \mu \mathrm{I}$ IVM medium in $5 \% \mathrm{O}_{2}$ ); Treatment $\mathbf{1 : 1 0 / 2 0 \%}$ (1 oocyte per $10 \mu \mathrm{IVM}$ medium in $20 \%$ $\mathrm{O}_{2}$ ); Treatment 1:20/5\% (1 oocyte per $20 \mu \mathrm{l}$ of IVM medium in 5\% $\mathrm{O}_{2}$ ); Treatment $\mathbf{1 : 2 0 / 2 0 \%}$ (1 oocyte per $20 \mu \mathrm{l}$ of IVM medium in $20 \% \mathrm{O}_{2}$ ).

Experiment I - Evaluation of nuclear and cytoplasmic maturation of in vitro matured oocytes under different oxygen tensions and oocyte densities

Nine replicates were performed for nuclear and cytoplasmic maturation assays (435 and 420 oocytes, respectively). For each treatment, nuclear and cytoplasmic maturation evaluations were performed 24 hours after maturation.

Experiment II - Evaluation of ROS production in oocytes and in IVMmedium, as well as the evaluation of the antioxidant system in in vitro matured oocytes under different oxygen tensions and oocyte densities ROS production in oocytes and ROS accumulation 
on IVM medium after 24 hours of maturation were evaluated using the spectrofluorimetric method in 420 oocytes (seven replicates). In all treatments, reduced glutathione and superoxide dismutase were also evaluated, using the spectrofluorimetric method (GSH) and a method based on epinephrine auto oxidation (SOD), in 360 oocytes (six replicates).

\section{Experiment III - IVF evaluation of in vitro matured} oocytes under different oxygen tensions and oocyte densities

In this experiment, seven replicates of IVF oocytes $(n=331)$ after 24 hours of IVM were examined to determine the influence of these IVM systems on fertilization, penetration and polyspermy rates.

\section{Results}

Experiment I: Evaluation of nuclear and cytoplasmic maturation of in vitro matured bovine oocytes

The nuclear maturation rates did not differ statistically among treatments $(1: 10 / 5 \%=70.5 \pm 10.2 \%$,
$1: 10 / 20 \%=72.6 \pm 18.7 \%, 1: 20 / 5 \%=67.2 \pm 13.2 \%$ and $1: 20 / 20 \%=68.18 \pm 13.3 \%$ ). All the treatments had cytoplasmic maturation rates of approximately $70 \%$ $(1: 10 / 5 \%=71.0 \pm 12.3 \%, \quad 1: 10 / 20 \%=73.91 \pm 15.8 \%$, $1: 20 / 5 \%=69.2 \pm 13.3 \%$ and $1: 20 / 20 \%=72.03 \pm 12.1 \%$ ). Similar percentages were obtained when nuclear and cytoplasmic maturation was evaluated.

Experiment II: Evaluation of ROS production in oocytes and in IVM medium as well as the activity ofantioxidant systems inin vitro maturedoocytes

Production of reactive oxygen species

The production of reactive oxygen species in oocytes matured in a $5 \% \mathrm{O}_{2}$ atmosphere was higher than that of oocytes matured in a $20 \% \mathrm{O}_{2}$ atmosphere (Fig. 1). Oocyte density by medium volume did not show any interference in oocyte ROS production. In contrast, ROS accumulation in the medium was higher in treatments with a density of 1 oocyte in $10 \mu \mathrm{l}$ of IVM medium than that of 1 oocyte in $20 \mu 1$ of IVM medium, regardless of the oxygen tension utilized during IVM (Figure 1).

Figure 1. Reactive oxygen species production in oocytes and in IVM medium after 24 hours of culture in 5 or $20 \%$ oxygen tension and 1:10 or 1:20 oocyte per microliters.

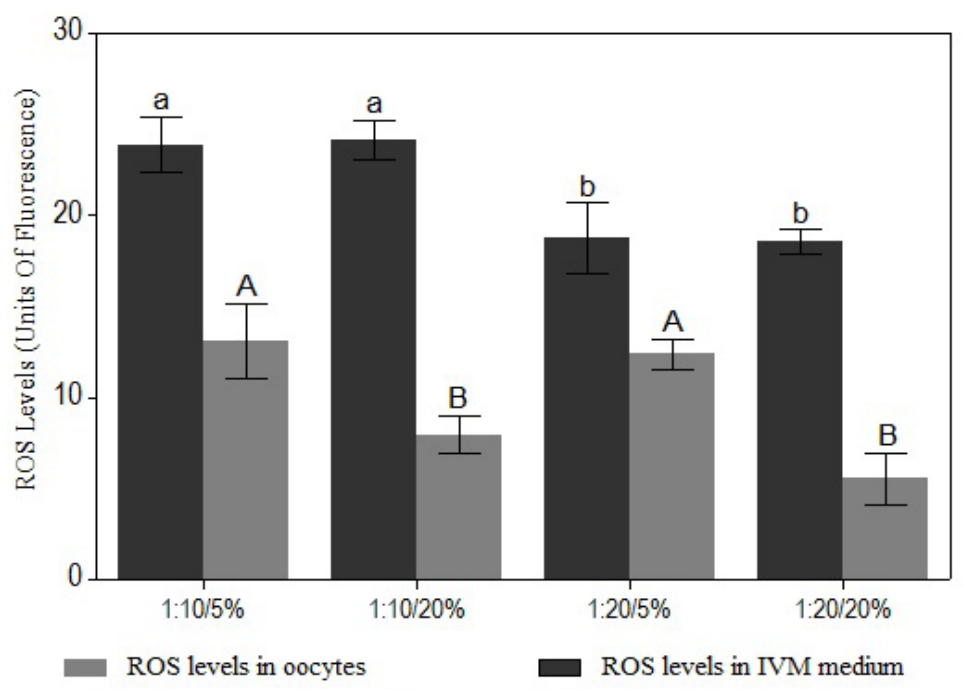

A, B, a, b: Different superscripts on the same colors bars show significant differences. $(\mathrm{p}<0.05)$

* Percentage based on total of evaluated oocytes. 


\section{Antioxidant system evaluation}

There was no difference in the GSH levels and SOD activity $(\mathrm{P}>0.05)$. The levels of GSH in oocytes were $1: 10 / 5 \%\left(7.43 \pm 1.42 \mathrm{nmol} / \mathrm{ml}^{-1}\right), 1: 10 / 20 \%$ $\left(7.21 \pm 1.95 \mathrm{nmol} / \mathrm{ml}^{-1}\right), 1: 20 / 5 \%(7.48 \pm 0.89 \mathrm{nmol}$ $\left.\mathrm{mL}^{-1}\right)$ and $1: 20 / 20 \%\left(5.7 \pm 0.82 \mathrm{nmol} / \mathrm{ml}^{-1}\right)$, whereas SOD activity was $1: 10 / 5 \% \quad(18.16 \pm 5.00 \mathrm{UI})$, $1: 10 / 20 \%(19.46 \pm 3.00 \mathrm{UI}), 1: 20 / 5 \%(23.64 \pm 4.23 \mathrm{UI})$ and $1: 20 / 20 \%(24.01 \pm 1.58 \mathrm{UI})$.

Experiment III: IVF evaluation of in vitro matured oocytes in different systems

Significant differences were observed among normal fertilization (NF), polyspermic penetration
(PP) and normal fertilization plus normal penetration $(\mathrm{PF})$. Normal penetration (NP) rates were not different among treatments $(\mathrm{P}>0.05)$. Fertilization rates were higher when $20 \%$ oxygen tension was associated with high oocyte density than when $5 \%$ oxygen tension was associated with high oocyte density (Table 1 ). The use of $20 \%$ oxygen tension associated with a lower oocyte density had higher polyspermic penetration rates than oocytes matured in $20 \%$ oxygen tension and high density. Normal penetration and normal fertilization data showed that the association of $20 \%$ oxygen tension with high oocyte density $(1: 10 / 20 \%)$ had higher rates than treatments $1: 10 / 5 \%$ and $1: 20 / 20 \%$. However, the rates from treatment $1: 10 / 20 \%$ were similar to treatment $1: 20 / 5 \%$ (Table 1 ).

Table 1. Percentages of normal fertilization (NF), normal penetration (NP), polyspermic penetration (PP), and penetration plus fertilization normal (PF) for in vitro matured oocytes under different oxygen tensions ( $5 \%$ or $20 \%$ ) and oocyte density media (1:10 or 1:20 oocyte per microliters).

\begin{tabular}{lccccccccc}
\hline \multirow{2}{*}{ Treatment } & Oocytes evaluated & \multicolumn{2}{c}{$\mathrm{NF}$} & \multicolumn{2}{c}{$\mathrm{NP}$} & \multicolumn{3}{c}{ PP } & \multicolumn{3}{c}{ PF } \\
\cline { 2 - 10 } & $\mathrm{n}$ & $\mathrm{n}$ & $\%$ & $\mathrm{n}$ & $\%$ & $\mathrm{n}$ & $\%$ & $\mathrm{n}$ & $\%$ \\
\hline $1: 10 / 5 \%$ & 88 & 16 & $18.1^{\mathrm{b}}$ & 10 & 11.4 & 19 & $21.6^{\mathrm{ab}}$ & 26 & $29.5^{\mathrm{b}}$ \\
$1: 10 / 20 \%$ & 82 & 29 & $35.4^{\mathrm{a}}$ & 11 & 13.4 & 11 & $13.4^{\mathrm{b}}$ & 40 & $48.8^{\mathrm{a}}$ \\
$1: 20 / 5 \%$ & 82 & 22 & $26.8^{\mathrm{ab}}$ & 11 & 13.4 & 15 & $18.3^{\mathrm{ab}}$ & 33 & $40.2^{\mathrm{ab}}$ \\
$1: 20 / 20 \%$ & 79 & 17 & $21.5^{\mathrm{ab}}$ & 6 & 7.6 & 22 & $27.8^{\mathrm{a}}$ & 23 & $29.1^{\mathrm{b}}$ \\
\hline
\end{tabular}

${ }^{\mathrm{ab}}$ Within a column, the means without a common letter differed $(\mathrm{P}<0.05)$.

\section{Discussion and Conclusion}

In cattle, beneficial (HASHIMOTO et al., 2000, 2009) and detrimental (CASTRO E PAULA; HANSEN, 2007; HANSEN, 2007; PINYOPUMMINTR; BAVISTER, 1995; WATSON et al., 2000) effects of low oxygen tension during IVM have been reported. Nevertheless, an optimal oxygen level for IVM has not been established, and the effect of the density of oocytes associated with oxygen tension has not been studied until now.

Our results showed that the oxygen tension and density of oocytes during IVM did not affect the rate of nuclear maturation and cytoplasmic maturation.
However, variations in the ROS production and fertilization rates of these oocytes were demonstrated, providing evidence of the influence of these factors on in vitro fertilization. The nuclear and cytoplasmic maturation rates (70 and $71 \%$ ) in Experiment I did not differ among treatments, which were independent of oxygen tension (5 or $20 \%$ ) or the oocyte density by medium volume (1:10 or 1:20), which indicated that, apparently, these systems of IVM did not affect the maturation process. Mingoti et al. (2011) demonstrated that $20 \%$ $\mathrm{O}_{2}$ tension during IVM improves rates of metaphase II. However, in most instances, only $30-35 \%$ of the matured oocytes reach the blastocyst stage, even 
with this high rate of in vitro maturation (BLONDIN et al., 2002; RIZOS et al., 2002), indicating that others factors affect oocyte maturation and future embryonic development. Nuclear maturation and the reorganization of mitochondria are essential for successful fertilization; however, other factors, such as the reorganization of cortical granules and mitochondrial activity, must be analyzed to give conclusive oocyte maturation rates.

High oxygen tension (20\%) in culture conditions may cause increases in the generation of ROS (FOWLER; CALLINGHAM, 1978; GUÉRIN et al., 2001; HASHIMOTO et al., 2000; YANG et al., 1998). At physiological levels, ROS are beneficial for many cellular functions (GOUD et al., 2008). To control ROS production, cells have a defense system, which produces antioxidants. In Experiment II, we demonstrated that $5 \%$ oxygen tension produced more ROS in oocytes compared with $20 \%$ oxygen tension, which was independent of the oocyte density utilized. The higher production of ROS under lower oxygen tension can be explained by the competition between oocytes and cumulus cells for the available oxygen (KIND et al., 2015; PINYOPUMMINTR; BAVISTER, 1995). In systems with low oxygen tension, cells may lack oxygen for energy generation, which causes an imbalance in ROS production and antioxidant defenses (SILVA et al., 2010). These data were confirmed when ROS production in IVM medium was evaluated. The system that had a higher concentration of oocytes per medium volume (1:10 $\mu 1)$ accumulated more ROS than the systems that utilized lower oocyte density (1:20 $\mu 1)$, which was independent of the oxygen tension utilized.

The maturation of bovine oocytes can be influenced by oxidative stress, which affects the maturation process and can cause several cell damage (AGARWAL et al., 2006), such as abnormal DNA segregation, mutations, the inactivation of mitochondrial DNA, the synthesis or storage of abnormal proteins, or the modification of the lipid composition of the membrane (GOUD et al., 2008).
According to Miyamura et al. (1995), GSH is synthesized during maturation, which increases in activity after IVM, whereas there is a decrease in SOD activity after maturation (CETICA et al., 2001). In Experiment II, such oxidative stress indicators were evaluated, which despite the increased production of ROS, these parameters did not change in the oocytes. Although there was an increased production of ROS in treatments with $5 \% \mathrm{O}_{2}$, we cannot confirm that the levels that were found were sufficient to generate an oxidative stress because the GSH levels and SOD activity were not altered. In swine, low oxygen tension does not increase GSH concentrations (BING et al., 2002). The fact that parameters, such as nuclear and cytoplasmic maturation and antioxidant defenses (GSH and SOD), did not differ among treatments does not mean that there were no other changes in the oocyte because these parameters are only reduced after a series of biochemical events that may occur in cells, such as the action of ROS on the cell membrane. ROS may affect other systems of maturation, such as the reorganization of cortical granules and the activity of mitochondria for ATP generation, which are closely connected with the fertilization rate (SILVA et al., 2010). During IVM, the $\mathrm{Ca}^{++}$release mechanisms are activated (WANG et al., 1997), and the reorganization of cortical granules is affected by oxidative stress (GOUD et al., 2008).

The polysperm rates were higher for the treatment that used $20 \%$ oxygen and low oocyte density, and which treatment presented lower ROS production, suggesting that the production of beneficial ROS may be insufficient for the reorganization of cortical granules, which functions to avoid polyspermy (MARQUES et al., 2012; WESSEL et al., 2001). In experiment III, the fertilization and penetration rates were affected by the association of oxygen tension and oocyte density per medium volume. The results demonstrated that the $20 \%$ oxygen tension associated with 1:10 $\mu$ l oocyte density was more beneficial than were the other treatments. ROS production in $20 \%$ oxygen tension 
was lower than that of $5 \% \mathrm{O}_{2}$, and when oxygen tension is associated with a high oocyte density, the development of fertilization was not negatively affected by accumulated ROS on the IVM medium. In contrast, the lower oocyte density associated with a low oxygen tension did not affect the fertilization rates. The interaction of oxygen tension with factors that affect maturation, fertilization and embryo development, such as media and glucose during the IVM of bovine oocytes have also been observed in other studies (CASTRO E PAULA; HANSEN, 2007; PEREIRA et al., 2010), corroborating with our findings.

The data obtained in the present study provide evidence of an interaction between oxygen tension and oocyte density during IVM, which influences further in vitro fertilization processes. The interaction between oxygen tension and oocyte densities that were utilized during the IVM period did not affect the maturation rates analyzed in this study. Additionally, certain associations of these factors caused an increased production of ROS, which, in turn, affected the in vitro fertilization of bovine oocytes. Improved rates of IVF were obtained when IVM was conducted using 20\% oxygen tension and high oocyte density $(1: 20 \mu \mathrm{l})$.

\section{References}

ABBOTT, A. L.; DUCIBELlA, T. Calcium and the control of mammalian cortical granule exocytosis. Frontiers in Bioscience, Tampa, v. 6, p. 792-806, jul. 2001. Available at: <http://www.ncbi.nlm.nih.gov/ pubmed/11438440>. Accessed at: 22 jul. 2014.

ADAM, A. A. G.; TAKAHASHI, Y.; NAGANO, S. K. M. Effects of oxygen tension in the gas atmosphere during in vitro maturation, in vitro fertilization and in vitro culture on the efficiency of in vitro production of mouse embryos. The Japanese Journal of Veterinary Research, Hokkaido, v. 52, n. 2, p. 77-84, aug. 2004. Available at: <http://www.ncbi.nlm.nih.gov/pubmed/15481861>. Accessed at: 17 oct 2013.

AGARWAL, A.; SAID, T. M.; BEDAIWY, M. A.; BANERJEE, J.; ALVAREZ, J. G. Oxidative stress in an assisted reproductive techniques setting. Fertility and Sterility, New York, v. 86, n. 3, p. 503-512, sept. 2006. Available at: <http://www.ncbi.nlm.nih.gov/ pubmed/16860798>. Accessed at: 25 jun. 2014.

BANWELL, K. M.; LANE, M.; RUSSELL, D. L.; KIND, K. L.; THOMPSON, J. G. Oxygen concentration during mouse oocyte in vitro maturation affects embryo and fetal development. Human Reproduction, Oxford, v. 22, n. 10, p. 2768-2775, oct. 2007. Available at: <http:// www.ncbi.nlm.nih.gov/pubmed/17725990>. Accessed at: 23 aug.2014.

BERMEJO-ALVAREZ, P.; LONERGAN, P.; RIZOS, D.; GUTIÉRREZ-ADAN, A. Low oxygen tension during IVM improves bovine oocyte competence and enhances anaerobic glycolysis. Reproductive Biomedicine Online, Cambridge, v. 20, n. 3, p. 341-349, mar. 2010. Available at: <http://www.ncbi.nlm.nih.gov/pubmed/20093090>. Accessed at: 22 jun. 2014.

BING, Y. Z.; HIRAO, Y.; CHE, M.; IGA, K.; TAKENOUCHI, N.; KUWAYAMA, M.; FUCHIMOTO, D.; MARTINEZ, H. R.; NAGAI, T. In vitro maturation and glutathione synthesis of porcine oocytes in the presence or absence of cysteamine under different oxygen tensions: role of cumulus cells. Reproduction, Fertility and Development, East Melbourne, v. 14, n. 3-4, p. 125-131, 2002. Available at: <http://www.ncbi.nlm. nih.gov/pubmed/12219933>. Accessed at: 12 jun 2014.

BLONDIN, P.; BOUSQUET, D.; HERMÉNÉGILDE, T.; BARNES, F.; SIRARD, M. A. Manipulation of follicular development to produce developmentally competent bovine oocytes. Biology of Reproduction, New York, v. 66, n. 1, p. 38-43, jan. 2002. Available at: <http://www. ncbi.nlm.nih.gov/pubmed/11751261>. Accessed at: 23 jun. 2014.

BRUM, D. S.; LEIVAS, F. G.; SILVA, C. A. M.; RUBIN, M. I. B.; RAUBER, L. P.; FIALHO, S. S.; BERNARDI, M. L. Animal Reproduction, Belo Horizonte, v. 2, n. 1, p. 70-73, 2005.

CASTRO E PAULA, L. A. de; HANSEN, P. J. Interactions between oxygen tension and glucose concentration that modulate actions of heat shock on bovine oocytes during in vitro maturation. Theriogenology, Stoneham, v. 68, n. 5, p. 763-770, sept. 2007. Available at: <http://www. ncbi.nlm.nih.gov/pubmed/17643482>. Accessed at: 2 jul. 2014.

CETICA, P.D.; PINTOS, L. N.; DALVIT, G. C.; BECONI, M. T. Antioxidant enzyme activity and oxidative stress in bovine oocyte in vitro maturation. IUBMB Life, London, v. 51, n. 1, p. 57-64, jan. 2001. Available at: <http://www. ncbi.nlm.nih.gov/pubmed/11419698>. Accessed at: 5 jul. 2014 
FOLCHINI, N. P.; LEIVAS, F. G.; SANTOS, F. W.; SCHWENGBER, D. R.; MARTIN, D. M.; SPIAZZI, C. C.; BRUM, D. S. Uso de Mini Percoll modificado para seleção e redução da formação de espécies reativas de oxigênio (ROS) em espermatozoides bovinos. Revista Brasileira de Reprodução Animal, Belo Horizonte, v. 36, n. 4, p. 239-244, 2012.

FOWLER, C. J.; CALLINGHAM, B. A. Substrateselective activation of rat liver mitochondrial monoamine oxidase by oxygen. Biochemical Pharmacology, Oxford, v. 27 , n. 16 , p. 1995-2000, 1978. Available at: <http:// www.ncbi.nlm.nih.gov/pubmed/718722>. Accessed at: 3 jan. 2014.

GOUD, A. P.; GOUD, P. T.; DIAMOND, M. P.; GORNIK, B.; ABU-SOUD, H. M. Reactive oxygen species and oocyte aging: role of superoxide, hydrogen peroxide, and hypochlorous acid. Free Radical Biology and Medicine, New York, v. 44, n. 7, p. 1295-1304, apr. 2008. Available at: <http://www.ncbi.nlm.nih.gov/pubmed/18177745>. Accessed at: 3 feb 2014.

GUÉRIN, P.; EL MOUATASSIM, S.; MÉNÉZO, $\mathrm{Y}$. Oxidative stress and protection against reactive oxygen species in the pre-implantation embryo and its surroundings. Human Reprod Update, Oxford, v. 7, n. 2, p. 175-189, mar./apr. 2001. Available at: <http://www. ncbi.nlm.nih.gov/pubmed/11284661>. Accessed at: 3 aug. 2014.

HANSEN, P. J. To be or not to be-determinants of embryonic survival following heat shock. Theriogenology, Stoneham, v. 68, p. S40-8, sept. 2007. Supplement 1. Available at: <http://www.ncbi.nlm.nih. gov/pubmed/17467047>. Accessed at: 27 sep. 2014

HASHIMOTO, S. Application of in vitro maturation to assisted reproductive technology. Journal of Reproduction and Development, Tokyo, v. 55, n. 1, p. 1-10, feb. 2009. Available at: <http://www.ncbi.nlm.nih. gov/pubmed/19276618>. Accessed at: 14 jan. 2014.

HASHIMOTO, S.; MINAMI, N.; TAKAKURA, R. Low oxygen tension during in vitro maturation is beneficial for supporting the subsequent development of bovine cumulus-oocyte complexes. Molecular Reproduction and Development, New York, v. 57, n. 4, p. 353-360, dec. 2000. Available at: <http://www.ncbi.nlm.nih.gov/ pubmed/11066064>. Accessed at: 17 mar. 2014.

HIRAO, Y.; SHIMIZU, M.; IGA, K.; TAKENOUCHI, N. Optimization of oxygen concentration for growing bovine oocytes in vitro: constant low and high oxygen concentrations compromise the yield of fully grown oocytes. Journal of Reproduction and Development, Tokyo, v. 58, n. 2, p. 204-211, 2012. Available at: <http:// www.ncbi.nlm.nih.gov/pubmed/22223441>. Accessed at: 14 mar. 2014.

HISSIN, P. J.; HILF, R. A fluorometric method for determination of oxidized and reduced glutathione in tissues. Analitycal Biochemistry, v. 74, n. 1, p. 214-226, jul. 1976. Available at: <http://www.ncbi.nlm.nih.gov/ pubmed/962076>. Accessed at: 8 feb. 2014.

KIND, K. L.; TAM, K. K. Y.; BANWELL, K. M.; GAULD, A. D.; RUSSELL, D. L.; MACPHERSON, A. M.; BROWN, H. M.; FRANK, L. A.; PEET, D. J.; THOMPSON, J. G.Oxygen-regulated gene expression in murine cumulus cells. Reproduction, Fertility and Development, East Melbourne, v. 27, n. 2, p. 407418, 2015. Available at: <http://dx.doi.org/10.1071/ RD13249>. Accessed at: 8 feb. 2014.

LEIVAS, F. G.; BRUM, D. S.; SALIBA, W. P.; ALVIM, M. T. T.; BERNARDI, M. L.; RUBIN, M. I. B.; SILVA, C. A. M. Oxygen tension in the IVM and IVF of bovine oocytes: Effect on the embryonic development and pregnancy rate. Animal Reproduction, Belo Horizonte, v. 3, n. 4, p. 439-445, 2006.

LOETCHUTINAT, C.; KOTHAN, S.; DECHSUPA, S.; MEESUNGNOEN, J.; JAY-GERIN, J. P.; MAKHETKORN, S. Spectrofluorometric determination of intracellular levels of reactive oxygen species in drug-sensitive and drug-resistant cancer cells using the 2', 7'-dichlorofluorescein diacetate assay. Radiation Physics and Chemistry, Oxford, v. 72, p. 323-331, 2005.

LONERGAN, P.; RIZOS, D.; GUTIERREZ-ADAN, A.; FAIR, T.; BOLAND, M. P. Oocyte and embryo quality: effect of origin, culture conditions and gene expression patterns. Reproduction in Domestic Animals, Berlin, v. 38, n. 4, p. 259-267, aug. 2003. Available at: <http:// www.ncbi.nlm.nih.gov/pubmed/12887565>. Accessed at: 7 jun. 2014.

LOOS, F. de; VAN VLIET, C.; VAN MAURIK, P.; KRUIP, T. A. Morphology of immature bovine oocytes. Gamete Research, New York, v. 24, n. 2, p. 197-204, oct. 1989. Available at: <http://www.ncbi.nlm.nih.gov/ pubmed/2793058 . Accessed at: 22 jan 2014.

MARQUES, M. G.; DE BARROS, F. R. O.; GOISSIS, M. D.; CAVALCANTI, P. V.; VIANA, C. H. C. ASSUMPÇÃO, M. E. O. D.; VISINTIN, J. A. Effect of low oxygen tension atmosphere and maturation media supplementation on nuclear maturation, cortical granules migration and sperm penetration in swine in vitro fertilization. Reproduction in Domestic Animals, Berlin, v. 47 , n. 3, p. 491-497, 2012. Available at: <http://www. ncbi.nlm.nih.gov/pubmed/21950674>. Accessed at: 13 jan. 2014. 
MATOS, D. G. de; FURNUS, C. C. The importance of having high glutathione (GSH) level after bovine in vitro maturation on embryo development effect of betamercaptoethanol, cysteine and cystine. Theriogenology, Stoneham, v. 53, n. 3, p. 761-771, feb. 2000. Available at: <http://www.ncbi.nlm.nih.gov/pubmed/10735042>. Accessed at: 5 apr. 2014.

MILLER, G. F.; RORIE, R. W. Effect of oxygen concentration during oocyte maturation on subsequent bovine embryo cleavage and development in vitro. Research Series - Arkansas Agricultural Experiment Station, Arkansas, v. 478, p. 43-44, 2000.

MINGOTI, G. Z.; CASTRO, V. S. D. C.; MÉO, S. C.; BARRETO, L. S. S.; GARCIA, J. M. The effects of macromolecular and serum supplements and oxygen tension during bovine in vitro procedures on kinetics of oocyte maturation and embryo development. In Vitro Cellular and Development Biology Animal, Gaithersburg, v. 47 , n. 5-6, p. 361-367, jun. 2011. Available at: <http:// www.ncbi.nlm.nih.gov/pubmed/21424239>. Accessed at: 13 apr. 2014.

MIYAMURA, M.; YOSHIDA, M.; HAMANO, S.; KUWAYAMA, M. Glutathione concentration during maturation and fertilization in bovine oocytes. Theriogenology, Stoneham, v. 48, n. 1, p. 282. 1995. Abstract.

O'DOHERTY, E. M.; WADE, M. G.; HILL, J. L.; BOLLAND, M. P. Effects of culturing bovine oocytes either singly or in groups on development to blastocysts. Theriogenology, Stoneham, v. 48, n. 1, p. 161-169, jul. 1997. Available at: <http://www.ncbi.nlm.nih.gov/ pubmed/16728116>. Accessed at: 23 jan. 2014

PEREIRA, M. M.; MACHADO, M. A.; SERAPIAO, R. V.; VIANA, J. H. M.; CAMARGO, L. S. A. Effect of oxygen tension and serum during IVM on developmental competence of bovine oocytes. Reproduction, Fertility and Development, East Melbourne, v. 22, n. 7, p. 10741082, 2010. Available at: <http://www.ncbi.nlm.nih.gov/ pubmed/20797345>. Accessed at: 17 jan. 2014.

PINYOPUMMINTR, T.; BAVISTER, B. D. Optimum gas atmosphere for in vitro maturation and in vitro fertilization of bovine oocytes. Theriogenology, Stoneham, v. 44, n. 4, p. 471-477, sept. 1995. Available at: $<$ http://www.ncbi.nlm.nih.gov/pubmed/16727746>. Accessed at: 3 feb. 2014.

RIZOS. D.; LONERGAN, P.; BOLAND, M. P.; ARROYOGARCÍA, R.; DE LA FUENTE, J.; GUTIÉRREZ-ADÁN, A. Analysis of differential messenger RNA expression between bovine blastocysts produced in different culture systems: implications for blastocyst quality. Biology of
Reproduction, New York, v. 66, n. 3, p. 589-595, mar. 2002. Available at: <http://www.ncbi.nlm.nih.gov/ pubmed/11870062>. Accessed at: 11 feb. 2015.

SILVA, C. G. M.; FAUSTINO, L. R.; SARAIVA, M. V. A.; ROSSETTO, R.; FIGUEIREDO, J. R. Influência da tensão de oxigênio na maturação oocitária e cultivo in vitro de folículos e embriões. Revista Brasileira de Reprodução Animal, Belo Horizonte, v. 34, n. 4, p. 233242, 2010.

STATISTICAL ANALYSIS SYSTEM INSTITUTE - SAS. SAS Institute Inc., 2001 SAS/IML ${ }^{\circledR}$ Software: Changes and Enhancements, Release 8. 2. Cary, NC: SAS Institute Inc, 2001.

STOJKOVIC, M.; MACHADO, S.; STOJKOVIC, P.; ZAKARTCHENKO, V.; HUTZLER, P.; GONÇALVES, P.; WOLF, E.; STOJKOVIC, M. Mitochondrial distribution and adenosine triphosphate content of bovine oocytes before and after in vitro maturation: correlation with morphological criteria and developmental capacity after in vitro fertilization and culture. Biology of Reproduction, v. 64, n. 3, p. 904-909, mar. 2001. Available at: <http://www.ncbi.nlm.nih.gov/pubmed/11207207>. Accessed at: 22 jan. 2014.

WANG, W. H.; SUM, Q. Y.; HOSOE, M.; SHIOYA, Y.; DAY, B. N. Quantified analysis of cortical granule distribution and exocytosis of porcine oocytes during meiotic maturation and activation. Biology of Reproduction, v. 56, n. 6, p. 1376-1382, jun. 1997. Available at: <http://www.ncbi.nlm.nih.gov/ pubmed/9166688>. Accessed at: 17 feb 2014.

WATSON, A. J.; SOUZA, P. de; CAVENEY, A.; BARCROFT, L. C.; NATALE, D.; URQUHART, J.; WESTHUSIN, M. E. Impact of bovine oocyte maturation media on oocyte transcript levels, blastocyst development, cell number, and apoptosis. Biology of Reproduction, v. 62, n. 2, p. 355-364, feb. 2000. Available at: <http://www.ncbi.nlm.nih.gov/pubmed/10642573>. Accessed at: 8 jun. 2014.

WESSEL, G. M.; BROOKS, J. M.; GREEN, E.; HALEY, S.; VORONINA, E.; WONG J.; ZAYDFUDIM, V.; CONNER, S. The biology of cortical granules. International Review of Cytology, v. 209, p. 117-206, 2001. Available at: <http://www.ncbi.nlm.nih.gov/ pubmed/11580200>. Accessed at: 17 jul. 2014.

YANG, H. W.; HWANG, K. J.; KWON, H. C.; KIM, H. S.; CHOI, K. W.; OH, K. S. Detection of reactive oxygen species (ROS) and apoptosis in human fragmented embryos. Human Reproduction, Oxford, v. 13, n. 4, p. 998-1002, apr. 1998. Available at: <http://www.ncbi.nlm. nih.gov/pubmed/9619561>. Accessed at 22 jul. 2014. 
